\title{
E-Modul Interaktif Muatan IPA Pada Sub Tema 1 Tema 5
}

\author{
Gusti Ngurah Komang Wiratama ${ }^{1}$, I Gede Margunayasa ${ }^{2}$ \\ 1,2 Program Studi Pendidikan Guru Sekolah Dasar, Universitas Pendidikan Ganesha, Singaraja, Indonesia
}

\section{ART ICLE INFO}

Article history:

Received March 09, 2021

Revised April 15, 2021

Accepted May 28, 2021

Available online July 25, 2021

Kata Kunci:

E-Modul Interaktif , Ekosistem

Keywords:

Interactive E-Module,

Ecosystem

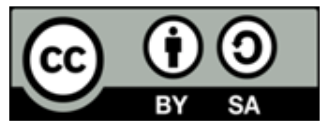

This is an open access article under the CC BY-SA license.

Copyright (๑) 2021 by Author. Published by Universitas Pendidikan Ganesha.

\begin{abstract}
A B S T R A K
Siswa seringkali mengalami kesulitan dalam memahami suatu topik bahasan akibatnya pembelajaran menjadi kurang efektif. Oleh sebab itu, perlu adanya pembaharuan dalam pembelajaran seperti E-modul interaktif. Penelitian ini bertujuan untuk mengembangkan E-Modul interaktif muatan IPA pada sub tema 1 tema yang teruji validitasnya. Penelitian ini merupakan penelitian pengembangan yang dilaksanakan dengan menggunakan model ADDIE dengan tatanan analisis, desain, pengembangan, implementasi, dan evaluasi. Subjek penelitian ini adalah 2 dosen ahli materi, 2 dosen ahli media dan 2 guru ahli praktisi. Metode pengumpulan data yang digunakan adalah metode kuisioner dengan menggunakan instrumen rating scale yang berupa lembar penilaian para ahli. Data yang diproleh dari hasil uji validitas kemudian diolah menggunakan rumus mean untuk mengetahui hasil rata-rata skor validitas. Hasil analisis menunjukkan bahwa rata-rata skor dari ahli materi 4.41, dari ahli media 4.73, dan dari praktisi 4.96. Hasil tersebut menunjukan e-modul interaktif yang dikembangkan termasuk dalam kualifikasi sangat baik. Dengan demikian maka E-Modul Interaktif muatan IPA pada sub tema 1 tema 5 kelas $\checkmark \mathrm{SD}$ dinyatakan valid dan dapat digunakan didalam proses pembelajaran di kelas V SD khususnya materi ekosistem.
\end{abstract}

\section{A B S T R A C T}

Students often have difficulty understanding a topic as a result of learning to be less effective. Therefore, there is a need for renewal in learning such as an interactive E-module. This study aims to develop an interactive E-Module on science content on sub-theme 1 theme whose validity has been tested. This research is development research carried out using the ADDIE model with an order of analysis, design, development, implementation, and evaluation. The subjects of this study were 2 material expert lecturers, 2 media expert lecturers and 2 expert practitioner teachers. The data collection method used was a questionnaire method using a rating scale instrument in the form of an expert assessment sheet. The data obtained from the results of the validity test are then processed using the mean formula to determine the average validity score. The results of the analysis show that the average score of material experts is 4.41, media experts are 4.73, and practitioners are 4.96. These results show that the interactive e-module developed is very well qualified. Thus, the Interactive E-Module for Natural Science content in sub-theme 1 theme 5 class V SD is declared valid and can be used in the learning process in grade V SD, especially ecosystem material.

\section{PENDAHULUAN}

Pembelajaran di era saat ini menuntut kita untuk dapat menggunakan teknologi dengan baik (Salsabila et al., 2020). Teknologi merupakan metode ilmiah untuk mencapai tujuan yang sederhana guna mencapai kelangsungan dan kenyamanan hidup manusia (Budiman, 2017). Menghadapi kemajuan teknologi dan informasi yang begitu cepat tentu diperlukan upaya-upaya yang dilakukan sebuah negara dalam mempersiapkan sumber daya manusia (SDM) yang berkualitas. Hal ini dapat dilakukan melalui proses pendidikan yang bermutu tinggi. Upaya awal dalam meningkatkan mutu pendidikan adalah dengan meningkatkan kualitas proses pembelajaran. Pembelajaran semestinya dirancang sedemikian rupa untuk membekali siswa kemampuan yang dibutunhkan dalam menghadapi berbagai tangtangan dimasa yang akan datang. Kemampuan ini meliputi kemampuan berpikir kritis, sistematis, dan kreatif dalam memecahkan permasalahan yang diwujudkan denagan proses pembelajaran bermakana (Rovers et al., 2018; Sung, 2017). Kemampuan tersebut merupakan kemampuan yang diharapkan dalam pendidikan abab 21 dan sebagai upaya kesiapan karier dimasa depan (Lavi et al., 2021). Visi pendidikan abad 21 yang lebih berdasarkan pada paradigma learning adalah belajar berpikir yang berorientasi pada pengetahuan logis dan rasional, belajar berbuat yang berorientasi pada bagaimana mengatasi masalah, 
belajar menjadi mandiri yang berorientasi pada pembentukan karakter, dan belajar hidup bersama yang berorientasi untuk bersikap toleran dan siap bekerjasama (Yuliati, 2017). Begitu pula dengan pembelajaran IPA di SD yang hendanknya dilakuan melalui proses pembelajaran yang inovatif dan membangkitkan motivasi belajar siswa. Pembelajaran IPA yang dilakukan dengan melibatkan aktivitas siswa secara langsung dalam beberbagai kegiatan ilmiah untuk sampai pada pemahaman sebuah konsep akan dirasa lebih bermakna oleh siswa (Darmawan et al., 2017; Dewi et al., 2017; Hendracipta, 2016). Pembelajaran yang berpusat pada siswa merupakan sebuah langkah inovatif dalam mengembangkan kemampuan siswa untuk membangun pengetahuannya secara mandiri dari berbagai pengalaman belajar (Amponsah et al., 2019). Guru memiliki peran penting dalam upaya membangun suasana pembelajaran yang berpusat pada aktivitas siswa, yaitu melalui pemilihan metode, model, dan media pembelajaran (Hastuti et al., 2019; Suandewi et al., 2017; Widyaiswara et al., 2019).

Namun, pada kenyataannya fakta di lapangan menunjukan proses pembelajaran khususnya IPA di SD belum berlangsung seperti yang diharapkan. Sebaran angket kuisioner yang telah dilaksanakan pada hari Selasa, 9 November 2020 diperoleh hasil 87,5\% guru kelas V SD mengatakan kesulitan dalam mengemas materi bahan ajar yang akan di sampaikan kepada siswa. Karena tidak semua guru bisa mengembangkan kreatisfitasnya dalam mengemas materi yang di sebabkan kurangnya kemampuan guru dalam menguasai IT. Sehingga hal ini mengakibatkan kurang maksimalnya penyampaian materi dalam proses pembelajaran sehingga pencapaian tujuan pembelajaran menjadi tidak maksimal. Akses pendidikan yang berkualitas memang menjadi salah satu hambatan bagi negara berkembang (Abdulrahaman et al., 2020). Hasil penelitian menyebutkan rendahnya hasil belajar IPA siswa karena proses pembelajaran masih berpusat pada guru dan materi yang disajikan masih sebatas hafalan sementara (Suparya, 2019). Selain itu, dalam proses pembelajaran guru belum mampu mengaplikasikan model dan media pembelajaran serta belum menghubungkan konsep-konsep yang dipelajari dengan kehidupan sehari-hari (Antari et al., 2019; Permana et al., 2017). Perhatian dan tingkat keaktifan siswa dalam membangun pengetahuannya secara mandiri masih dalam kategori rendah, dibuktikan dari rendahnya keinginan siswa dalam membaca buku ataupun sumber-sumber belajar lainnya (Nithyanandama, 2020; Suryantari et al., 2019). Hasil studi PISA tahun 2018 menyatakan kemampuan sains siswa Indonesia masih dibawah rata-rata, yang dibuktikan dari perolehan skor Indonesia adalah 389, sedangkan skor rata-ratanya, adalah 489 (Indriani, 2019). Apabila permasalahan ini tidak segera ditangani tentu akan berdampak buruk pada kualitas SDM Indonesia kedepannya.

Upaya yang dapat dilakukan untuk mengatasi permasalahan tersebut adalah melakukan sebuah revolusi dalam proses pembelajaran yang berlangsung selama ini. Revolusi ini dimulai dari pergeseran paradigma yang sebelumnya pembelajaran berpusat pada guru menjadi berpusat pada aktivitas siswa. Siswa secara aktif dan kreatif membangun pengetahuannya sendiri, sedangkan guru hanya berperan sebagai fasilitator. Oleh sebab itu, diperlukan sebuah sumber belajar yang mendukung terwujudnya susana pembelajaran yang demikian dan dengan memanfaatkan kemajuan teknologi sekarang ini, salah satu alternatifnya adalah mengembangkan $e$ modul interaktif. E-modul adalah dokumen atau artikel yang disusun sedemikian rupa dalam bentuk elektronik yang memiliki banyak manfaat (Solikin, 2018; Sugihartini \& Jayanta, 2017). Sementara itu, e-modul interaktif adalah bahan pembelajaran yang berisi materi, metode, batasan-batasan, dan cara mengevaluasi yang dirancang secara sistematis dan menarik untuk mencapai suatu kompetensi yang diharapkan (Imansari \& Sunaryantiningsih, 2017). Hasil penelitian menyatakan penerapan model guided inquiry berbantuan e-modul dapat meningkatkan keterampilan berpikir kritis siswa (Budiarti et al., 2016). Hasil penelitian lainnya juga menyebutkan penggunaan e-modul dalam proses pembelajaran berdampak signifikan terhadap peningkatan hasil belajar siswa (Dewi \& Lestari, 2020; Herawati \& Muhtadi, 2018; Laili et al., 2019). Namun kelemahan dari beberpa penelitan tersebut adalah belum ada yang mengembangkan e-modul interaktif muatan IPA pada sub tema 1 tema 5 kelas V SD. Sehingga pada penelitian ini dilakukan pengembangan e-modul interaktif muatan IPA pada sub tema 1 tema 5 kelas V SD. Kelebihan e-modul interaktif yang dikembangkan pada penelitian ini, yaitu: bisa memfasilitasi siswa dalam proses pembelajaran daring ditengah kondisi pandemi Covid-19, dilengkapi dengan gambar-gambar, memiliki perpaduan warna yang menarik, dan memiliki kesesuaian dengan karakteristik siswa dan topik bahasan yang diambil. Melalui pengembangan e-modul interaktif ini diharapkan proses pembelajaran khususnya muatan IPA berlangsung lebih baik, yaitu pembelajaran yang mengutamakan aktivitas siswa dalam membangun pengetahuannya dan tercipta pembelajaran yang bermakana. Dan pada akhirnya berdampak pada peningkatan hasil belajar siswa.

\section{METODE}

Penelitian ini merupakan penelitian pengembangan media pembelajaran yang dimuat dalam E-Modul yang memiliki tujuan agar dapat mempermudah guru dan siswa dalam menerima dan menyampaikan materi yang ingin diajarkan. Penelitian pengembangan memiliki tujuan untuk fokus menghasilkan dan mengembangkan produk yang layak dan efektif digunakan dalam pembelajaran sehingga permasalahan pembelajaran dapat diselesaikan dengan produk yang dikembangakan (Tegeh \& Kirna, 2013). Di dalam pengembangan E-Modul ini 
harus melalui beberapa tahapan. Adapun tahapan-tahapan itu mengacu pada model ADDIE (analisis, perencanaan, pengembangan, implementasi, dan evaluasi) (Cahyadi, 2019). subjek penelitian ini terdiri dari 2 orang ahli materi, 2 orang ahli media, 2 orang guru. Untuk ahli materi dan ahli media merupakan dosen dari Fakultas Ilmu Pendidikan di Universitas Pendidikan Ganesha dengan kualifikasi keahlian minimal tingkat S1. Sedangkan untuk praktisi merupakan guru sekolah dasar yang telah memiliki pengalaman mengajar di sekolah. Objek penelitian ini menggunakan validitas e-modul interaktif pada muatan IPA sub tema 1 tema 5 kelas V SD di gugus IV Buleleng. Tahapan yang digunakan pada penelitian ini yaitu tahap analisis, tahap perancangan dan tahapan pengembangan. Pada tahap implementasi dan evaluasi, tidak dilaksanakan karena melihat kondisi dan keadaan dimasa sekarang. Langkah-langkah penelitian pengembangan disajikan pada Gambar 01.

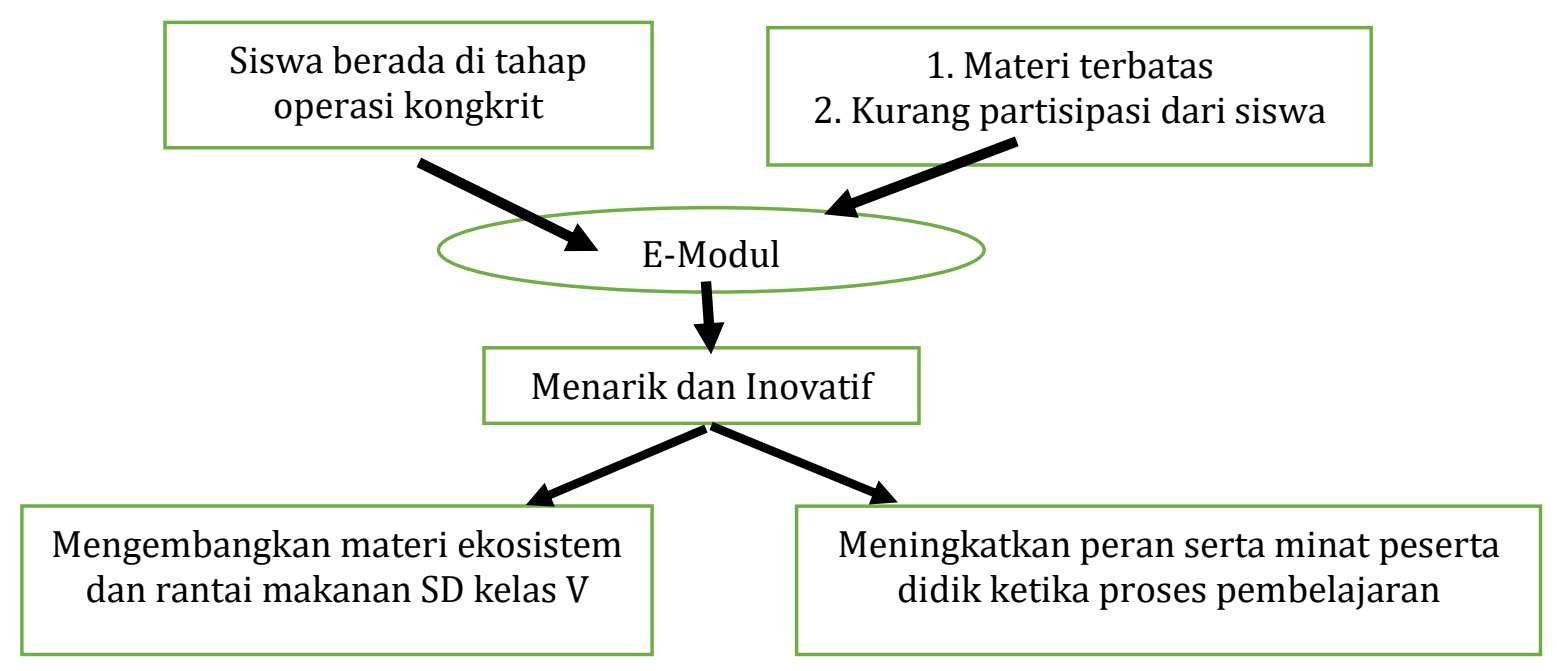

Gambar 1. Langkah-langkah Penelitian Pengembangan

Metode pengumpulan data yang diguankan adalah metode non tes berupa kuesioner (angket). Metode pengumpulan data menggunakan kuisioner dilaksanakan dengan memberikan sebuah daftar pertanyaan atau pernyataan-pernyataan kepada responden (Agung, 2014). kuisioner dalam penelitian ini berbentuk rating scale yang menggunakan lembar penilaian e-modul interaktif (Ilhami \& Rimantho, 2017). Dalam upaya memastikan validitas suatu instrument harus melalui beberapa tahap yakni: 1) Membuat tabel kisi-kisi validitas bahan ajar yang akan mencangkup 6 aspek yakni, sampul, format, isi, Bahasa, praktis dan efektifitifitas. Ke enam aspek di atas akan di kemas kedalam instrumen sesuai dengan aspek-aspeknya. 2) Kriteria dalam penilaian yang pertama ini yakni menilai keserasian sampul dan identitas dari bahan ajar yang dihasilkan meliputi tata letak tulisan, warna dan huruf, kriteria yang ke 3 ini mencangkup kecocokan antara indikator dengan materi, kemampuan bahan ajar dalam membantu penyampaian materi dalam proses pembelajaran, (4) Aspek Bahasa meliputi kaaktifan Bahasa, kebakuan, penyusunan kata, (5) Kepraktisan media dalam pengoperasiannya, (6) Kriteria aspek efektif memiliki keterkaitan dengan penggunaan media. Sedangkan Instrumen yang digunakan pada penelitian, yaitu rating scale. Skala yang digunakan pada rating scale adalah 1-4 (Ilhami \& Rimantho, 2017b). Adapun kisi-kisi lembar validitas untuk ahli bahan ajar, ahli materi dan praktisi dapat dilihat pada Tabel 01,02 dan 03.

Tabel 1. Kisi-kisi Lembar Validasi Ahli Media E-Modul Interaktif Muatan IPA

\begin{tabular}{|c|c|c|c|c|}
\hline No & Aspek & Dimensi & $\begin{array}{c}\text { Jumlah } \\
\text { Butir }\end{array}$ & $\begin{array}{c}\text { Nomor } \\
\text { Butir }\end{array}$ \\
\hline \multirow[t]{3}{*}{1} & \multirow[t]{3}{*}{ Organisasi } & Kesesuaian gambar/video yang ada dengan materi yang disajikan. & 1 & 1 \\
\hline & & Keterbacaan teks pada e-modul interaktif. & 1 & 2 \\
\hline & & Kelengkapan bagian - bagian modul & 1 & 3 \\
\hline \multirow[t]{2}{*}{2} & \multirow[t]{2}{*}{ Daya Tarik } & Kemenarikan penampilan isi e-modul interaktif. & 1 & 4 \\
\hline & & Kemenarikan penampilan soal- soal & 1 & 5 \\
\hline \multirow[t]{5}{*}{3} & \multirow{5}{*}{$\begin{array}{l}\text { Huruf dan } \\
\text { gambar }\end{array}$} & Warna huruf dan gambar sesuai & 1 & 6 \\
\hline & & Bentuk huruf dan gambar sesuai & 1 & 7 \\
\hline & & Penggunaan bahasa mengacu pada EYD. & 1 & 8 \\
\hline & & Ketepatan penggunaan dan penulisan bahasa asing. & 1 & 9 \\
\hline & & Kejelasan kata dan istilah yang digunakan. & 1 & 10 \\
\hline
\end{tabular}


Tabel 2. Kisi-kisi Lembar Validasi Praktisi E-Modul Interaktif Muatan IPA

\begin{tabular}{|c|c|c|c|c|}
\hline No & Aspek & Dimensi & $\begin{array}{c}\text { Jumlah } \\
\text { Butir }\end{array}$ & $\begin{array}{c}\text { Nomor } \\
\text { Butir }\end{array}$ \\
\hline \multirow[t]{3}{*}{1} & Organisasi & Kesesuaian gambar/video yang ada dengan materi yang disajikan. & 1 & 1 \\
\hline & & Keterbacaan teks pada e-modul interaktif. & 1 & 3 \\
\hline & & Kelengkapan bagian - bagian modul & 1 & 3 \\
\hline \multirow[t]{2}{*}{2} & Daya Tarik & Kemenarikan penampilan isi modul & 1 & 4 \\
\hline & & Kemenarikan penampilan soal- soal & 1 & 5 \\
\hline \multirow[t]{5}{*}{3} & Huruf dan & Warna huruf dan gambar sesuai & 1 & 6 \\
\hline & gambar & Bentuk huruf dan gambar sesuai & 1 & 7 \\
\hline & & Penggunaan bahasa mengacu pada EYD. & 1 & 8 \\
\hline & & Ketepatan penggunaan dan penulisan bahasa asing. & 1 & 9 \\
\hline & & Kejelasan kata dan istilah yang digunakan. & 1 & 10 \\
\hline \multirow[t]{9}{*}{4} & Self & Kejelasan tujuan pembelajaran. & 1 & 11 \\
\hline & instruction & Pengemasan materi pembelajaran menarik dan jelas. & 1 & 12 \\
\hline & & Materi pembelajaran didukung dengan contoh dan ilustrasi. & 1 & 13 \\
\hline & & $\begin{array}{l}\text { Ketersediaan soal dan tugas untuk mengukur penguasaan peserta } \\
\text { didik. }\end{array}$ & 1 & 14 \\
\hline & & $\begin{array}{l}\text { Tugas dan soal yang disajikan relevan dengan materi, konteks } \\
\text { kegiatan dan lingkungan peserta didik. }\end{array}$ & 1 & 15 \\
\hline & & Penggunaan bahasa yang sederhana dan komunikatif. & 1 & 16 \\
\hline & & Ketersediaan rangkuman materi pembelajaran. & 1 & 17 \\
\hline & & Ketersediaan instrumen penilaian. & 1 & 18 \\
\hline & & Ketersediaan umpan balik atas penilaian peserta didik. & 1 & 19 \\
\hline 5 & $\begin{array}{l}\text { Self } \\
\text { contained }\end{array}$ & Memuat seluruh materi pembelajaran satu standar kompetensi & 1 & 20 \\
\hline 6 & Adaptive & E-modul mengadaptasi perkembangan teknologi. & 1 & 21 \\
\hline \multirow[t]{2}{*}{7} & User friendly & Instruksi mudah digunakan. & 1 & 22 \\
\hline & & Informasi mudah digunakan. & 1 & 23 \\
\hline
\end{tabular}

Tabel 3. Kisi-kisi Lembar Validasi Ahli Materi E-Modul Interaktif Muatan IPA

\begin{tabular}{|c|c|c|c|c|}
\hline No & Aspek & Dimensi & $\begin{array}{c}\text { Jumlah } \\
\text { Butir }\end{array}$ & $\begin{array}{c}\text { Nomor } \\
\text { Butir }\end{array}$ \\
\hline \multirow[t]{9}{*}{1} & Selfinstruction & Kejelasan tujuan pembelajaran. & 1 & 1 \\
\hline & & Pengemasan materi pembelajaran menarik dan jelas. & 1 & 2 \\
\hline & & Materi pembelajaran didukung dengan contoh dan ilustrasi. & 1 & 3 \\
\hline & & $\begin{array}{l}\text { Ketersediaan soal dan tugas untuk mengukur penguasaan peserta } \\
\text { didik. }\end{array}$ & 1 & 4 \\
\hline & & $\begin{array}{l}\text { Tugas dan soal yang disajikan relevan dengan materi, konteks } \\
\text { kegiatan dan lingkungan peserta didik. }\end{array}$ & 1 & 5 \\
\hline & & Penggunaan bahasa yang sederhana dan komunikatif. & 1 & 6 \\
\hline & & Ketersediaan rangkuman materi pembelajaran. & 1 & 7 \\
\hline & & Ketersediaan instrumen penilaian. & 1 & 8 \\
\hline & & Ketersediaan umpan balik atas penilaian peserta didik. & 1 & 9 \\
\hline 2 & Self contained & Memuat seluruh materi pembelajaran satu standar kompetensi. & 1 & 10 \\
\hline 3 & Adaptive & E-modul interaktif mengadaptasi perkembangan teknologi. & 1 & 11 \\
\hline \multirow[t]{2}{*}{4} & User friendly & Instruksi mudah digunakan. & 1 & 12 \\
\hline & & Informasi mudah digunakan. & 1 & 13 \\
\hline
\end{tabular}

Metode analisis data yang digunakan dalam penelitian ini adalah metode analisis deskriptif kualitatif dan analisis deskriptif kuantitatif. Metode analisis kualitatif merupakan data yang diperoleh pada tahap review ahli berupa saran dan komentar, selanjutnya dari data tersebut dilakukan perbaikan terhadap media yang dikembangkan sesuai dengan saran dan komentar yang diberikan sehingga menjadi media yang lebih baik lagi. Sedangkan data kuantitatif merupakan data yang diperoleh pada tahap review ahli berupa skor pada lembar penilaian, kemudian data tersebut dihitung rata-ratanya dengan menggunakan rumus mean guna mendapatkan hasil validitas dari media yang dikembangkan. Setelah rata-ratanya diperoleh selanjutnya dikonversikan dengan tabel konversi tingkat pencapaian skala 5. Instrumen yang telah disusun selanjutnya dilakukan tahap uji validitas. Uji validitas dilakukan untuk mengetahui tingkat kevalidan instrumen tersebut dengan menggunakan rumus Gregory. 


\section{HASIL DAN PEMBAHASAN}

\section{Hasil}

Penelitian yang dilakukan merupakan Penelitian pengembangan dengan tujuan untuk mengmbangkan media E-Modul interaktif muatan IPA pada Tema 5 Sub Tema 1 kelas V SD dengan materi ekosistem. Media EModul interaktif muatan IPA pada Tema 5 Sub Tema 1 kelas V SD diujicobakan kepada 2 orang ahli materi, 2 orang ahli media, 2 orang guru. Penelitian ini dilaksanakan dengan menggunakan model ADDIE, dengan tahapan analisis, perencanaan, pengembangan, implementasi, dan evaluasi.

\section{Tahap Analisis}

Pada tahap analisis media telah melewati beberapa tahap yang meliputi: analisis kebutuhan, analisis kurikulum, analisis karakteristik siswa, dan analisis media yang baik. Pada Analisis kebutuhan yang dilakukan sebelum mengembangkan E-modul interaktif yang akan dilakukan di gugus IV Buleleng dilakukan menggunakan metode sebaran angket kuisioner. Berdasarkan hasil sebaran angket kuisioner didapatkan hasil Permasalahan yang terjadi diatas juga terjadi di Gugus IV Buleleng diperoleh hasil yakni dari 8 guru kelas V SD 87,5\% mengatakan kesulitan dalam mengemas materi bahan ajar yang akan di sampaikan kepada siswa. Karena tidak semua guru bisa mengembangkan kreatifitasnya dalam mengemas materi yang di sebabkan karena kurangnya kemampuan guru dalam menguasai IT. Sehingga hal ini mengakibatkan kurang maksimalnya penyampaian materi dalam proses pembelajaran sehingga pencapaian tujuan pembelajaran menjadi tidak maksimal. Dengan adanya kemajuan teknologi saat ini, siswa juga cenderung lebih akrab dengan HP daripada bermain dengan teman sejawatnya. Untuk itu perlu diadakan perbaharuan-perbaharuan dalam proses pembelajaran baik dari segi metode maupun model pembelajaran agar siswa menjadi lebih tertarik dalam mengikuti proses pembelajaran IPA sehingga dapat memaksimalkan dalam pencapaian tujuan pembelajaran. Salah satunya adalah perbaikan pembelajaran dengan menggunakan E-Modul dapat memudahkan guru dalam pengemasan materi dan penyampaian materi bahan ajar yang akan diajarkan kepada peserta didik dapat diterima dengan mudah dan cepat dipahami.

Analisis kurikulum dilaksanakan dengan cara menganalisis indikator dan kompetensi dasar yang ada didalam buku guru dan buku siswa kelas $\mathrm{V}$ tema 5 sub tema 1 yang akan menjadi acuan dalam pengembangan materi di dalam E-Modul interaktif. Berdasarkan hasil KD dan indicator pada tabel 04, maka dikembangkanlah Emodul berpatokan dengan KD di atas. Sedangkan hasil dari analisis karakteristik siswa yang dilakukan dapat diketahui bahwa karakteristik siswa SD berada pada tahap perkembangan operasional konkret umur 7-11 tahun khususnya pada perkembangan kognitif anak. Dari hal itu, maka saat proses pembelajaran diperlukannya sebuah alat guna membantu memperjelas siswa dalam mengartikan sebuah materi. Alat tersebut ialah sebuah media. Oleh sebab itu pemanfaatan media sangat penting guna membuat proses pembelajaran menjadi lebih optimal sesuai dengan perkembangan anak. Dengan adanya penggunaan media saat proses pembelajaran khususnya dalam hal ini media E-modul mampu menanamkan konsep pada suatu pembelajran. Kompetensi dasar yang diambil dalam penelitian ini adalah menganalisis hubungan antara komponen ekosistem dan daur hidup hewan di lingkungan sekitar dengan indikator menemukan hubungan antara komponen ekosistem dan daur hidup di lingkungan sekitar

Selanjutnya, analisis media dilaksanakan guna mengetahui informasi mengenai kelayakan dan kualitas media yang baik. Di dalam pengembangan E-Modul interaktif ini meliputi aspek sampul, format, isi, bahasa, kepraktisan, dan efektivitas. Aspek sampul meliputi identitas media dan kemenarikan sampul, aspek format meliputi warna, tulisan, huruf, dan tata letak, aspek isi meliputi kecocokan materi dengan indikator, kemampuan media menjelaskan materi, kelengkapan materi, dan daya tarik materi pada media, kriteria aspek bahasa meliputi penggunaan bahasa, kebakuan bahasa, keefektifan kalimat, dan penggunaan kata, serta kepraktisan dan efektivitas media yang dikembangkan. Maka dari itu media yang baik harus mempunyai kriteria sebagai berikut: (1) Kualitas isi materi dan tujuan harus sesuai dengan isi KD maupun SK, (2) Kualitas dari segi kemudahan untuk digunakannya serta kualitas dari media yang baik, (3) Kualitas dari segi instruksional yang mengutamakan kesempatan belajar, membantu belajar, serta mampu memberikan dorongan semangat kepada siswa (Arsyad, 2011).

\section{Tahap Perancangan}

Pada tahap perencanaan dilakukan untuk merancang media yang akan dibuat berdasarkan analisis yang telah dilakukan. Pembuatan media ini diawali dengan proses mendonload aplikasi CANVA yang dapat diunduh secara gratis di google playstore, setelah mengunduh aplikasi CANVA dilanjutkan mulai merancang cover dari Emodul dan merancang disain background dari media ini. Ukuran kertas yang digunakan adalah ukuran kertas A4. Setelah dirasa cukup proses selanjutnya adalah memasukkan materi-materi, gambar, audio dan video yang berkaitan dengan materi di dalam E-Modul. Sedangkan tahap yang terakhir adalah tahap pembuatan suatu instrument penilaian berupa soal objektif dan esai melalui google form. Media yang akan disajikan didalam penelitian ini berupa link yang akan menuju ke halaman E-Modul. Adapun rancangan media yang telah dibuat dapat dilihat pada gambar 02 . 


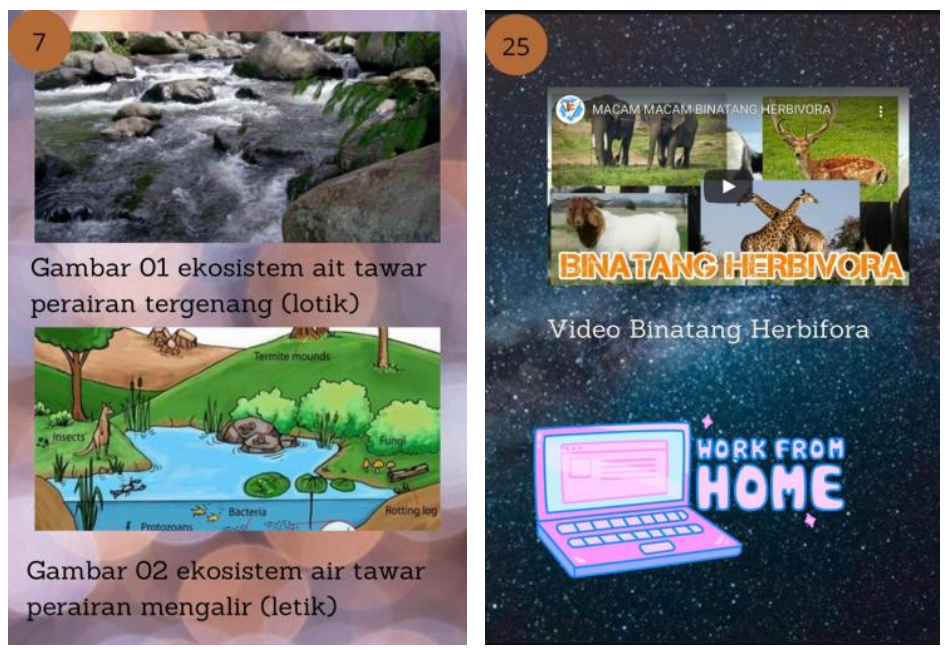

Gambar 2. Desain media

\section{Tahap Pengembangan}

Pada tahap pengembangan, media sudah mulai disempurnakan media yang dikembangkan mulai dari cover, KD dan indikator, petunjuk penggunaan, daftar isi, bagian isi, serta latihan soal dan hasil dapat langsung dilihat setelah menjawab soal-soal yang tersedia. Pada Sampul E-Modul interaktif ini didisain dan menyesuaikan gambar dengan tulisan agar mudah di baca dan menyesuaikan background cover agar sesuai dengan tema dari materi yang berada didalam media ini. Selanjutnya pada Bagian isi dari media ini adalah materi muatan IPA Pada Kelas V Tema 5 Sub Tema 1 Ekosistem yang meliputi jenis-jenis ekosistem, rantai makanan dan daur hidup hewan. Setelah melewati beberapa tahapan pengembangan E-modul yang telah dibuat selanjutnya akan uji coba E-modul untuk mengetahui tingkat validitas media yang telah dikembangkan agar layak untuk dibelajarkan. Adapun hasil media yang telah melewati beberapa tahap revisi dapat disajikan pada Gambar 02. Adapun hasil validitas E-modul Interaktif muatan IPA sub tema 1 tema 5 kelas V SD dapat disajikan pada Gambar 02,03, dan 04 .

Berdasarkan Gambar 02. dinyatakan bahwa skor rata-rata self Intruktion 4,1, self contained 5,28 Adaptive 5, dan user friendly 4,2. Dapat dijatakan bahwa skor rata-rata semua aspek E-Modul interaktif muatan IPA yang telah dinilai apabila dikonveksikan berdasarkan pedoman skala 5 berada pada rentangan $4.00 \leq x \leq 5.00$. hal ini menyatakan semua aspek E-Modul interaktif muatan IPA yang telah dinilai memiliki kualifikasi sangat baik. Berdasarkan dari Gambar 03. dinyatakan bahwa skor rata-rata Organisasi 4,7, Daya Tarik 4,5, Huruf dan gambar 4,7, User Friendly 4,7 dan adaptive 5. Dapat dinyatakan bahwa skor rata-rata semua aspek E-Modul interaktif muatan IPA yang telah dinilai apabila dikonveksikan berdasarkan pedoman skala 5 berada pada rentangan $4.0<\mathrm{X} \leq 5.0$. hal ini menyatakan semua aspek E-Modul interaktif muatan IPA yang telah dinilai memiliki kualifikasi sangat baik. Berdasarkan Gambar 04. dinyatakan bahwa skor rata-rata organisasi 5, Daya Tarik 4,7 Huruf dan gambar 5, serf intruktional 4,9, serf contained 5, user friendly 5 adaptive 5. Dapat dijatakan bahwa skor rata-rata semua aspek E-Modul interaktif muatan IPA yang telah dinilai apabila dikonveksikan berdasarkan pedoman skala 5 berada pada rentangan $4.0<x \leq 5$. . Hal ini menyatakan semua aspek E-Modul interaktif muatan IPA yang telah dinilai memiliki kualifikasi sangat baik. Berdasarkan hasil penelitian tersebut dapat dikatakan bahwa media E-modul pada materi muatan IPA Pada Kelas V Tema 5 Sub Tema 1 Ekosistem topik gaya siswa kelas IV SD secara menyeluruh dari hasil penilaian para ahli telah layak atau valid untuk dipergunakan dalam proses pembelajaran.

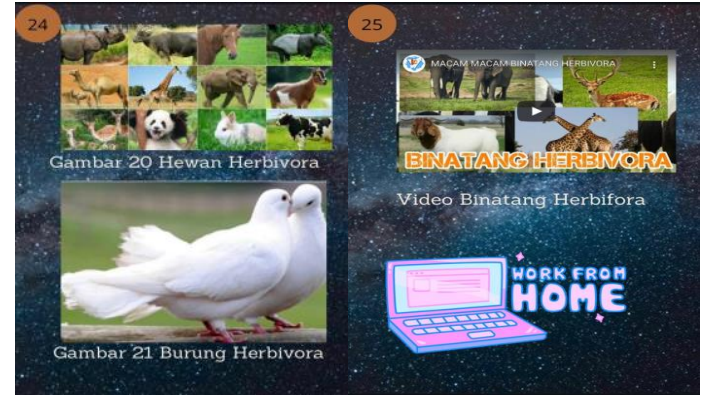

Gambar 3. Hasil Media yang Sudah Jadi

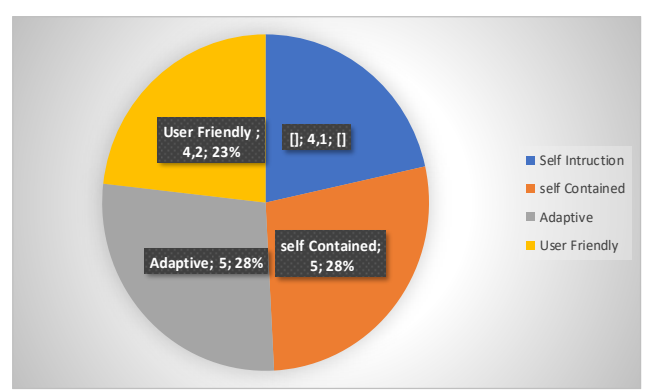

Gambar 4. diagram linngkaran Ahli Materi 


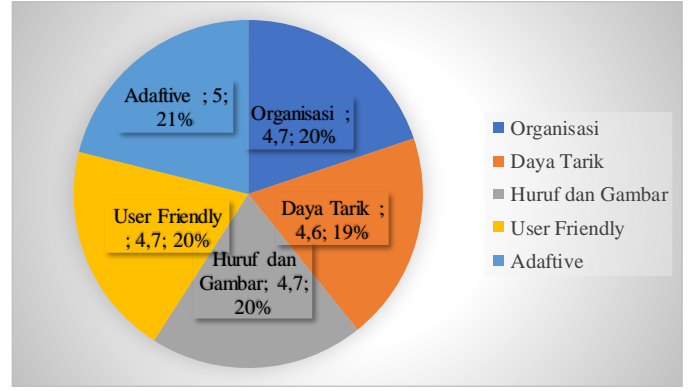

Gambar 4. diagram linngkaran Ahli Media

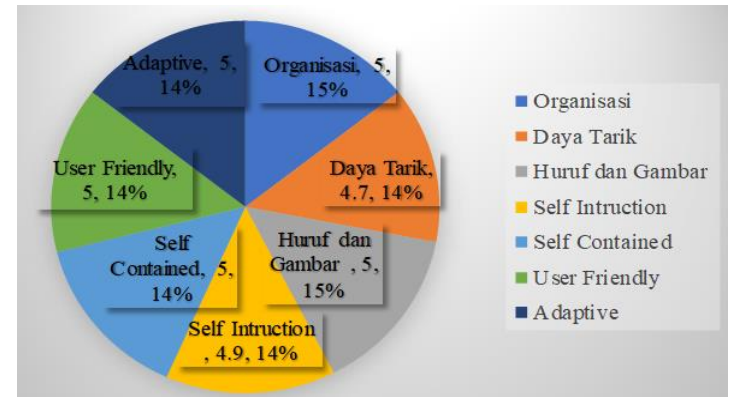

Gambar 5. Diagram Lingkaran Ahli Praktisi

\section{Pembahasan}

Tahap pendefinisian merupakan hal pertama yang mendasari pengembangan E-modul interaktif yang menunjukkan bahwa dari 8 guru kelas V SD 87,5\% mengatakan kesulitan dalam mengemas materi bahan ajar yang akan di sampaikan kepada siswa. Karena tidak semua guru bisa mengembangkan kreatifitasnya dalam mengemas materi yang di sebabkan karena kurangnya kemampuan guru dalam menguasai IT. E-modul yang dikembangkan memiliki validitas isi yang tinggi serta respons yang tinggi. Hal tersebut dikarenakan tujuan dari pembelajaran dalam media E-modul sudah sesuai dengan KD, materi dalam E-modul disampaikan secara jelas dan runtut serta sesuai dengan tingkat perkembangan karakteristik siswa, dan penjelasan materi pada E-modul dapat mendorong rasa ingin tahu siswa, dan validitas isi media E-modul mendapat kriteria validitas tinggi oleh ahli materi. Serta isi maupun konten dari materi dalam E-modul ditampilkan secara jelas, media E-modul dapat diakses melalui berbagai media elektronik. Bahasa dalam E-modul mudah untuk dipahami, tampilan dari media E-modul menarik, dan validitas isi media E-modul mendapat kriteria validitas tinggi oleh ahli media. Penelitian ini sejalan dengan penelitian yang menyatakan bahwa penggunaan Bahasa dan tampilan yang menarik membuat antusis siswa dalam mengikuti pembelajaran menjadi semakin meningkat (Kuncahyono, 2018; Nalarita, Y., 2018).

Tahap Perancangan merupakan proses merancang media yang akan dibuat berdasarkan analisis yang telah dilakukan. Media E-modul interaktif yang dikembangkan dapat memfasilitasi siswa dengan gaya belajar visual dan kinestik. Siswa yang memiliki gaya belajar visual dapat memahami materi yang disampaikan dengan cara mengamati gambar dan video yang ada didalam E-Modul interaktif, sedangkan siswa yang memiliki gaya belajar kinestik siswa juga dapat belajar secara langsung dan terlibat didalam proses penyampaiaman materi yang sedang disampaikan. Penelitian ini juga didukung oleh penelitian yang menyatakan bahwa dengan membuat media yang memiliki unsur audio visual, dapat menyampaikan sebuah materi menjadi lebih mudah dipahami dan lebih jelas (Atmaji \& Maryani, 2018; Bire et al., 2014; Hilmi, 2017). Pengembangan dari E-modul Interaktif yang dikembangkan berbeda dengan E-modul interaktif lainnya dikarenakan belum ada peneliti lain yang mengembangkan E-Modul interaktif sejenis Muatan IPA pada Sub Tema 1 Tema 5 kelas V SD Materi Ekosistem. Disamping itu, pembuatan E-Modul interaktif juga dilengkapi dengan adanya gambar, video, audio dan quis yang dapat membantu guru dan siswa didalam proses pembelajaran. E-modul Interaktif ini dikembangkan berdasarkan hasil analisis kebutuhan yang dilaksanakan dengan cara sebaran angket kuisioner kepada guru-guru sekolah dasar di Gugus 4 Buleleng. Sehingga E-modul interaktif inilah yang menjadi solusi dalam pemecahan masalah yang terjadi di Gugus 4 Buleleng. Penggunaan E-Modul interaktif sejalan dengan teori konstruktivisme yang lebih menekankan keterlibatan siswa didalam proses pembelajaran secara langsung yang diperoleh dari pengalamnnya secara langsung (Budiarti \& Riwanto, 2021; Santoso, 2017). Hal tersebut dinyatakan sesuai, karena di dalam penggunaan E-Modul interaktif siswa dituntut harus terlibat secara langsung didalam pengoperasian E-Modul interaktif baik membuka halaman, mendengar video dan audio mengamati gambar, membaca teks wacana dan menjawab quisis yang terdapat didalam E-Modul interaktif tersebut. Dengan pemberian pengalaman baru dan ikut secara langsung didalam proses pembelajaran maka siswa akan mampu memahami materi yang disampaikan secara cepat dan utuh.

Berdasarkan hasil yang telah dipaparkan dapat dikatakan bahwa produk yang dikembangkan layak digunakanan sebagai media pembelajaran bagi siswa sekolah dasar. Penelitian tersebut juga sejalan dengan penelitian yang menyatakan bahwa, secara teoritis siswa sekolah dasar berada pada tahap operasi kongkrit didalam proses pembelajarannya (Zakiah \& Khairi, 2019). Sehingga, masalah ini dapat diatasi dengan bantuan EModul interaktif yang telah dikembangkan. Adapun keunggulan dari E-Modul interaktif Muatan IPA Pada Sub Tema 1 Tema 5 kelas V SD adalah sebagai berikut: (1) E-modul ini dapat memudahkan guru dalam menyampaikan materi, karena di dalam E-modul tidak hanya berisikan teks-teks melainkan juga dapat disisipkan gambar-gambar, animasi dan juga video untuk membantu siswa dalam mengilustrasikan materi yang lebih abstrak. (2) E-modul guru juga dapat memberikan soal-soal berupa quizis yang dapat menambah wawasan dan mengevaluasi sejauh mana tujuan pembelajaran telah tercapai. (3) Memberikan suasana baru belajar yang 
baru kepada peserta didik sehingga siswa tidak cepat merasa bosan dalam mengikuti pembeljaran yang telah dilaksanakan (Anggraini, 2018; Jampel \& Puspita, 2017; Kurniawan \& Piyana, 2019).

Penelitian serupa juga juga berpendapat bahwa E-modul mempunyai beberapa kelebihan diantaranya yaitu: (1) Peserta didik dapat melaksanakan proses pembelajatan secara mandiri dan dapat memahami materi secara cepat berdasarkan kecepatan setiap individu dalam menerima materi bahan ajar yang di ajarkan. (2) Emodul merupakan paket lengkap ketika kegiatan belajar mengajar berlangsung yang mengakibatkan dalam luaran yang diinginkan sesuai. (3) E-modul memiliki nilai validitas yang tinggi karena sebelum E-modul disebar E-modul harus melalui uji validitas terlebih dahulu sebelum dipakai di dalam proses pembelajaran. Sedangkan jikalau ditinjau dari aspek sajian E-Modul interaktif ini yakni: (1) E-Modul interaktif muatan IPA pada Sub Tema 1 Tema 5 Kelas V SD dapat diakses kapan saja dan dimana saja sesuai dengan keinginan penggunanya. (2) Struktur warna dan tampulan yang dimiliki E-Modul interaktif sangat menarik, (3) Tidak membutuhkan ruang untuk penyimpanannya, (4) Disetiap slide dilengkapi gambar, audio dan video yang berhubungan dengan materi yang disampaikan (Maharcika, 2021). Hasil penelitian berupa E-Modul interaktif muatan IPA pada Sub Tema 1 Tema 5 kelas V SD memiliki implikasi sebagai bahan ajar interaktif untuk meningkatkan keaktifan serta kemandirian siswa dalam pembelajaran sehingga hal tersebut berepengaruh untuk mengembangkan kreatifitasnya dalam mengemas materi yang telah disampaikan.

\section{SIMPULAN}

E-Modul interaktif muatan IPA pada Sub Tema 1 Tema 5 kelas V SD memiliki kualifikasi sangat baik dari ahli materi, ahli media, dan praktis. Hal ini menunjukan bahwa e-modul interaktif muatan IPA pada Sub Tema 1 Tema 5 kelas V SD yang dikembangkan valid, sehingga e-modul interaktif ini layak untuk digunakan dalam proses pembelajaran.

\section{DAFTAR PUSTAKA}

Abdulrahaman, M. D., Faruk, N., A.A. Oloyede b, N. T. S.-B., Olawoyin, L. A., Mejabi, O. V., Imam-Fulani, Y. O., Fahm, A. O., \& Azeez, A. L. (2020). Multimedia tools in the teaching and learning processes: A systematic review. Heliyon, 6(11), 1-14. https://doi.org/10.1016/j.heliyon.2020.e05312.

Agung, A. A. G. (2014). Metode Penelitian Pendidikan. Aditya Media Publishing. https://doi.org/10.33394/bjib.v8i1.2657.

Amponsah, S., Kwesi, A. B., \& Ernest, A. (2019). Lin's creative pedagogy framework as a strategy for fostering creative learning in Ghanaian schools. Thinking Skills and Creativity, 31, 11-18. https://doi.org/10.1016/j.tsc.2018.09.002.

Anggraini, D. R. (2018). Pengembangan E-Modul Materi Energi Dan Perubahannya Dengan Pendekatan Saintifik Kelas IV SD/MI. (Doctoral Dissertation, UIN Raden Intan Lampung). http://dx.doi.org/10.23887/jjpgsd.v9i2.34805.

Antari, N. L. G. S., Pudjawan, K., \& Wibawa, I. M. C. (2019). Pengaruh Model Pembelajaran Kooperatif Tipe Course Review Horay Berbantuan Media Gambar Terhadap Hasil Belajar IPA. International Journal of Elementary Education, 3(2), 116-123. http://dx.doi.org/10.23887/ijee.v3i2.18512.

Arsyad, A. (2011). Media Pembelajaran. PT Raja Grafindo Persada.

Atmaji, R. D., \& Maryani, I. (2018). Pengembangan E-Modul Berbasis Literasi Sains Materi Organ Gerak Hewan dan Manusia Kelas V SD. Fundamental Pendidikan Dasar, 1(1), 28-34. https://doi.org/10.12928/fundadikdas.v2i1.687.

Bire, A. L., Geradus, U., \& Bire, J. (2014). Pengaruh Gaya Belajar Visual, Auditorial, Dan Kinestetik Terhadap Prestasi Belajar Siswa. Jurnal Kependidikan: Penelitian Inovasi Pembelajaran, 44(2). https://doi.org/10.21831/jk.v44i2.5307.

Budiarti, S., Nuswowati, M., \& Cahyono, E. (2016). Guided Inquiry Berbantuan E-Modul Untuk Meningkatkan Keterampilan Berpikir Kritis. Journal of Innovative Science Education, 5(2), 144-151. https://journal.unnes.ac.id/sju/index.php/jise/article/download/14264/7795.

Budiarti, W. N., \& Riwanto, M. A. (2021). Pengembangan Modul Elektronik (E Modul) Keterampilan Berbahasa Dan Sastra Indonesia SD Untuk Meningkatkan Keterampilan Menyimak Mahasiswa PGSD. Elementary School: Jurnal Pendidikan Dan Pembelajaran Ke-SD-An, 8(1), 97-104. https://doi.org/10.31316/esjurnal.v8i1.996.

Budiman, H. (2017). Peran Teknologi Informasi Dan Komunikasi Dalam Pendidikan. Al-Tadzkiyyah: Jurnal Pendidikan Islam, 8(1), 31-43. https://doi.org/10.24042/atjpi.v8i1.2095.

Cahyadi, R. A. H. (2019). Pengembangan Bahan Ajar Berbasis Addie Model. Halaqa: Islamic Education Journal, 3(1), 35. https://doi.org/10.21070/halaqa.v3i1.2124.

Darmawan, I. P. A. W., Suniasih, N. W., \& Manuaba, I. B. S. (2017). Pengaruh Model Pembelajaran Quantum Terhadap Hasil Belajar IPA Siswa Kelas V Gugus I Kecamatan Mengwi. Mimbar PGSD, 5(3), 1-9. 
https://doi.org/10.23887/jjpgsd.v5i3.12422.

Dewi, M. S. A., \& Lestari, N. A. P. (2020). E-Modul Interaktif Berbasis Proyek Terhadap Hasil Belajar Siswa. Jurnal Imiah Pendidikan Dan Pembelajaran, 4(3), 433-441. http://dx.doi.org/10.23887/jipp.v4i3.28035.

Dewi, P. P. Y., Manuaba, I. S., \& Suniasih, N. W. (2017). Pengaruh Model Pembelajaran Group Investigation Berbasis Proyek Terhadap Hasil Belajar Ipa Siswa Kelas IV. International Journal of Elementary Education, 1(4), 264. https://doi.org/10.23887/ijee.v1i4.12957.

Hastuti, H. W., Baedowi, S., \& Mushafanah, Q. (2019). Keefektifan Model Pembelajaran Numbered Heads Together Berbantu Media Panelpa (Papan Flanel IPA) Terhadap Hasil Belajar. International Journal of Elementary Education, 3(2), 108-115. http://dx.doi.org/10.23887/ijee.v3i2.18513.

Hendracipta, N. (2016). Menumbuhkan Sikap Ilmiah Siswa Sekolah Dasar Melalui Pembelajaran IPA Berbasis Inkuiri. JPsd Jurnal Pendidikan Sekolah Dasar), 2(1), 109-116. http://dx.doi.org/10.30870/jpsd.v2i1.672.

Herawati, N. S., \& Muhtadi, A. (2018). Pengembangan modul elektronik (e-modul) interaktif pada mata pelajaran Kimia kelas XI SMA. Jurnal Inovasi Teknologi Pendidikan, 5(2), 180-191. https://doi.org/10.21831/jitp.v5i2.15424.

Hilmi, H. (2017). Efektivitas Penggunaan Media Gambar Dalam Pembelajaran Bahasa Arab. Lantanida Journal, 4(2), 128-135. http://dx.doi.org/10.22373/lj.v4i2.1885.

Ilhami, R. S., \& Rimantho, D. (2017a). Penilaian Kinerja Karyawan dengan Metode AHP dan Rating Scale. Jurnal Optimasi Sistem Industri, 16(2), 150. https://doi.org/10.25077/josi.v16.n2.p150-157.2017.

Ilhami, R. S., \& Rimantho, D. (2017b). Penilaian Kinerja Karyawan dengan Metode AHP dan Rating Scale. Jurnal Optimis Sistem Industri, 16(2), 150-157. https://doi.org/10.25077/josi.v16.n2.p150-157.2017.

Imansari, N., \& Sunaryantiningsih, I. (2017). Pengaruh Penggunaan E-Modul Interaktif Terhadap Hasil Belajar Mahasiswa pada Materi Kesehatan dan Keselamatan Kerja. VOLT: Jurnal Ilmiah Pendidikan Teknik Elektro, 2(1), 11. https://doi.org/10.30870/volt.v2i1.1478.

Jampel, I. N., \& Puspita, K. R. (2017). Peningkatan Hasil Belajar Siswa Sekolah Dasar Melalui Aktivitas Pembelajaran Mengamati Berbantuan Audiovisual. International Journal of Elementary Education, 1(3), 197-102. https://doi.org/10.23887/ijee.v1i3.10156.

Kuncahyono, K. (2018). Pengembangan E-Modul Dalam Pembelajaran Tematik Di Sekolah Dasar. JMIE (Journal of Madrasah Ibtidaiyah Education), 2(2), 219-231. http://dx.doi.org/10.32934/jmie.v2i2.75.

Kurniawan, D. A., \& Piyana, S. O. (2019). E-Modul Etnokontruktivisme: Implementasi Pada Kelas V Sekolah Dasar Ditinjau Dari Persepsi, Minat Dan Motivasi. JTP-Jurnal Teknologi Pendidikan, 21(2), 165-177. https://doi.org/10.21009/jtp.v21i2.11030.

Laili, I., Ganefri, \& Usmeldi. (2019). Efektivitas Pengembangan E-Modul Project Based Learning Pada Mata Pelajaran Instalasi. Jurnal Imiah Pendidikan Dan Pembelajaran, 3, 306-315. http://dx.doi.org/10.23887/jipp.v3i3.21840.

Lavi, R., Tal, M., \& Dori, Y. J. (2021). Perceptions of STEM alumni and students on developing 21st century skills through methods of teaching and learning. Studies in Educational Evaluation, 70, 1-11. https://doi.org/10.1016/j.stueduc.2021.101002.

Maharcika, A. A. (2021). Pengembangan Modul Elektronik (E-Modul) Berbasis Flipbook Maker Untuk Subtema Pekerjaan Di Sekitarku Kelas IV SD/MI. (Doctoral Dissertation, Universitas Pendidikan Ganesha). https://doi.org/10.23887/jurnal_pendas.v5i2.240.

Nalarita, Y., \& L. (2018). Pengembangan E-Modul Kontesktual Interaktif Berbasis Web Pada Mata Pelajaran Kimia Senyawa Hidrokarbon. Multitek Indonesia, 12(2), 85-94. https://doi.org/10.24269/mtkind.v12i2.1125.

Nithyanandama, G. K. (2020). A framework to improve the quality of teaching-learning process a case study. Procedia Computer Science, 172, 92-97. https://doi.org/10.1016/j.procs.2020.05.013.

Permana, I. P. B. A., Dibia, I. K., \& Dharsana, I. K. (2017). Pengaruh Model Pembelajaran PBL Untuk Meningkatkan Hasil Belajar IPA Melalui Lesson Study SD Kelas V. Mimbar PGSD, 5(3), 1-11. https://doi.org/10.23887/jjpgsd.v5i3.12063.

Rovers, S. F. E., Clarebout, G., Savelberg, H. H. C. M., \& van Merriënboer, J. J. G. (2018). Improving student expectations of learning in a problem-based environment. Computers in Human Behavior, 87, 416-423. https://doi.org/10.1016/j.chb.2018.02.016.

Salsabila, U. H., Sari, L. I., Lathif, K. H., Lestari, A. P., \& Ayuning, A. (2020). Peran Teknologi Dalam Pembelajaran Di Masa Pandemi Covid-19. Al-Mutharahah: Jurnal Penelitian Dan Kajian Sosial Keagamaan, 17(2), 188-198. https://doi.org/10.46781/al-mutharahah.v17i2.138.

Santoso. (2017). Panduan Praktis Penyusun e-Modul Pembelajaran. Direktorat Jenderal Pendidikan Dasar dan Menengah. 2017_final_edit.pdf.

Solikin, I. (2018). Implementasi E-Modul pada Program Studi Manajemen Informatika Universitas Bina Darma Berbasis Web Mobile. JURNAL RESTI (Rekayasa Sistem Dan Teknologi Informasi), 2(2), 492-497. https://doi.org/10.29207/resti.v2i2.393. 
Suandewi, N. P., Dibia, I. K., \& Dharsana, I. K. (2017). Pengaruh Model Pembelajaran Nos Untuk Meningkatkan Hasil Belajar IPA Melalui Lesson Study Siswa Kelas V. Mimbar PGSD, 5(3), 1-11. https://doi.org/10.23887/jjpgsd.v5i3.12061.

Sugihartini, N., \& Jayanta, N. L. (2017). Pengembangan E-Modul Mata Kuliah Strategi Pembelajaran. Jurnal Pendidikan Teknologi Dan Kejuruan, 14(2), 221-230. http://dx.doi.org/10.23887/jptkundiksha.v14i2.11830.

Sung, E. (2017). The influence of visualization tendency on problem-solving ability and learning achievement of primary school students in South Korea. Thinking Skills and Creativity, 26, 168-175. https://doi.org/doi:10.1016/j.tsc.2017.10.

Suparya, I. K. (2019). Pengaruh Model Pembelajaran Kooperatif Tipe Think Talk Write (TTW) Terhadap Hasil Belajar Dan Kemampuan Berpikir Kritis Pada Pembelajaran IPA Di Sekolah Dasar. Jurnal Pendidikan, $\begin{array}{llll}\text { Agama Dan } & \text { Budaya, } & \text { 19-24. }\end{array}$ http://jurnal.stahnmpukuturan.ac.id/index.php/widyacarya/article/view/95.

Suryantari, N. M. A., Pudjawan, K., \& Wibawa, I. M. C. (2019). Pengaruh Model Pembelajaran Inkuiri Terbimbing Berbantuan Media Benda Konkret Terhadap Sikap Ilmiah dan Hasil Belajar IPA. International Journal of Elementary Education, 3(3), 316-326. http://dx.doi.org/10.23887/ijee.v3i3.19445.

Tegeh, I. M., \& Kirna, I. M. (2013). Pengembangan Bahan Ajar Metode Penelitian Pendidikan dengan ADDIE Model. Jurnal Pendidikan, 11(1), 16. http://dx.doi.org/10.23887/ika.v11i1.1145.

Widyaiswara, G. P., Parmiti, D. P., \& Suarjana, I. M. (2019). Pengaruh Model Pembelajaran Contextual Teaching and Learning terhadap Hasil Belajar IPA. International Journal of Elementary Education, 3(4), 389-395. http://dx.doi.org/10.23887/ijee.v3i4.21311.

Yuliati, Y. (2017). Literasi Sains Dalam Pembelajaran IPA. Jurnal Cakrawala Pendas. https://doi.org/10.31949/jcp.v3i2.592.

Zakiah, \& Khairi, F. (2019). Pengaruh Kemampuan Kognitif Terhadap Prestasi Belajar Matematika Siswa Kelas V Sdn Gugus 01 Kecamatan Selaparang. El Midad, 11(1), 85-100. https://doi.org/10.20414/elmidad.v11i1.1906. 